\title{
The Subcellular Localization of Glyoxylate Cycle Enzymes in Coprinus lagopus (sensu Buller)
}

\author{
By J. O'SULLIVAN* AND P. J. CASSELTON \\ Botany Department, Birkbeck College (University of London), \\ Malet Street, London, $W C_{\mathrm{I}} \mathrm{F}_{7} H X$
}

(Received Io Nolember 1972)

\begin{abstract}
SUMMAR Y
The derepression and localization of the glyoxylate cycle enzymes in Coprinus lagopus (sensu Buller) have been studied. Differential and sucrose density gradient centrifugation of extracts indicated a particulate localization for isocitrate lyase (EC. 4.I.3.I) and malate synthase (EC. 4. I.3.2). The particle is distinct from, and less dense than, the mitochondrion and is considered to be a glyoxysome.
\end{abstract}

\section{INTRODUCTION}

Anaplerotic metabolic pathways, such as the glyoxylate cycle, effect the conversion of growth substrate into cell material when micro-organisms are grown with $\mathrm{C}_{2}$ compounds as the sole source of carbon (Kornberg, 1966). Whilst the glyoxylate cycle has a number of reactions in common with the tricarboxylic acid cycle, there is considerable evidence that these two cycles are spatially separated in the eukaryotic cell. For example, in Tetrahymena pyriformis (Müller, Hogg \& De Duve, I 968), Neurospora crassa (Kobr, Vanderhaeghe \& Combépine, I969), yeast (Szabo \& Avers, I969) and Ricinus communis endosperm (Breidenbach, Kahn \& Beevers, I968; Cooper \& Beevers, 1969) at least some of the enzymes of the glyoxylate cycle are located in an organelle separable from the mitochondrion and variously called a glyoxysome or a peroxisome (De Duve, 1969; Avers, I97I ; Tolbert, 197I). This spatial separation may provide a basis for the regulation of the activities of the two pathways (Beevers, 1969). The localization of some glyoxylate-cycle enzymes in the basidiomycete Coprinus lagopus is discussed in this paper.

\section{METHODS}

Growth of fungus and preparation of extracts. H9, a wild-type monokaryotic strain of Coprinus lagopus (sensu Buller), was grown in a medium, buffered at $\mathrm{pH} 6.5$ with $0.05 \mathrm{M}-$ potassium phosphate, containing I I m m-glucose, $37.5 \mathrm{~mm}-\left(\mathrm{NH}_{4}\right)_{2} \mathrm{SO}_{4}, 295 \mu \mathrm{M}$ thiamine, and trace elements (Fries, 1953). The buffer, glucose and trace element solutions were autoclaved separately. Oidia were inoculated into $250 \mathrm{ml}$ portions of the medium in 2.31 penicillin flasks (Jencons Ltd, Hemel Hempstead) to a final concentration of about $\mathrm{I}^{6} / \mathrm{ml}$. Cultures were incubated on a rotary shaker $(80 \mathrm{rev} . / \mathrm{min})$ at $25^{\circ} \mathrm{C}$. Actively growing cultures in glucose medium were harvested by centrifugation, washed in saline, $(0.9 \%, \mathrm{w} / \mathrm{v})$ and inoculated into fresh medium containing $242 \mathrm{~mm}$-sodium acetate (Hopkin and Williams A. R. grade) in place of glucose. Mycelial samples were stored at $-20^{\circ} \mathrm{C}$ after harvesting until required.

* Present address: Institute of Microbiology, Swiss Federal Institute of Technology, Universitätstrasse 2, 8006 Zurich, Switzerland. 
Extracts were prepared by blending mycelium in a Virtis $\mathrm{Hi}$-speed 45 Homogenizer (Gardiner, New York, U.S.A.) for two periods of I min each at $5{ }^{\circ} \mathrm{C}$. The extraction medium was $0.2 \mathrm{M}$-potassium phosphate, $\mathrm{pH} 7 \cdot 0$, when estimation of total mycelial enzyme activity was undertaken, whilst a sucrose $(0.25 \mathrm{M}), \mathrm{Na}_{2}$ EDTA $(0.005 \mathrm{M})$, bovine serum albumin $(0.15 \%$, w/v) medium, $\mathrm{pH} 7 \cdot 0$, was used when localization studies were carried out (Hall \& Greenawalt, 1967).

Fractionation of extracts. Crude mycelial homogenates were subjected to two preliminary centrifugations at $1000 \mathrm{~g}$ for $10 \mathrm{~min}$ (Hall \& Greenawalt, 1967 ) yielding a supernatant (SI) and a particulate fraction (PI). SI was then centrifuged at $10000 \mathrm{~g}$ for $30 \mathrm{~min}$ resulting in a crude mitochondrial fraction $\left(\mathrm{P}_{2}\right)$ and a supernatant $\left(\mathrm{S}_{2}\right)$. $\mathrm{S}_{2}$ was recentrifuged at $35000 \mathrm{~g}$ for 30 min giving rise to a pellet $\left(\mathrm{P}_{3}\right)$ and a supernatant $\left(\mathrm{S}_{3}\right)$. Suspensions of $\mathrm{P}_{2}$ and $\mathrm{P}_{3}$ in $0.25 \mathrm{M}$-sucrose were combined for fractionation by sucrose density gradient centrifugation. Discontinuous sucrose gradients $(60$ to $20 \% ; 2.26$ to $0.63 \mathrm{M}$ ) were prepared manually and allowed to stand overnight at $5{ }^{\circ} \mathrm{C}$ after which the gradients were approximately linear, as assessed by refractive index measurements. Samples $(2 \mathrm{ml})$ were layered onto the top of the gradient to give a total volume of $20 \mathrm{ml}$. Centrifugation for $90 \mathrm{~min}$ was carried out in a $3 \times 23 \mathrm{ml}$ swing-out rotor, by means of an MSE Automatic Superspeed 50 Ultracentrifuge at $30000 \mathrm{rev} . / \mathrm{min}(65000 / \mathrm{I} 20000 \mathrm{~g})$. The gradients were sampled in $\mathrm{I} \mathrm{ml}$ fractions from the base of the centrifuge tube.

Enzyme assays. Isocitrate lyase (EC. 4.I.3.I) was assayed by the spectrophotometric method of Kornberg (1965); one enzyme unit was defined as giving rise to I nmol glyoxylate/ min under the conditions of the assay. Malate synthase (EC. 4.1.3.2) was assayed colorimetrically (Flavell \& Fincham, 1968); one enzyme unit was defined as giving rise to I nmol coenzyme A/min. Malate dehydrogenase (EC. I. I. I.37) was assayed by the method of Ochoa (1955); one enzyme unit being that amount which oxidized I $\mu \mathrm{mol} \mathrm{NADH} / \mathrm{min}$. Cytochrome oxidase was assayed by the method of Smith (1955) and enzyme activity expressed as $K$ values. Protein was measured by the method of Lowry, Rosebrough, Farr \& Randall (I95I). Specific activities are expressed as enzyme units/mg protein.

\section{RESULTS}

\section{Derepression of glyoxylate cycle enzymes}

Glucose-grown mycelium was harvested, washed and resuspended in a medium containing acetate as sole carbon source. Mycelial samples were extracted and the specific activities of isocitrate lyase, malate synthase and malate dehydrogenase were determined. Isocitrate lyase specific activity reached a maximum some $\mathrm{I} 2 \mathrm{~h}$ after transfer of the mycelium to acetate medium, while the other two enzymes continued to increase in specific activity beyond this time, although at a slower rate. There was approximately an eightfold increase in isocitrate lyase and malate synthase specific activities after $\mathrm{I} 2 \mathrm{~h}$, when compared to the repressed level, while that of malate dehydrogenase had increased about thirty times.

\section{Differential centrifugation}

Extracts of mycelium that had been transferred to acetate medium were fractionated by the methods outlined and the specific activities of isocitrate lyase, malate synthase, malate dehydrogenase and cytochrome oxidase determined in each of the pellet and supernatant fractions. The results showed that isocitrate lyase, cytochrome oxidase and, to a lesser extent, malate synthase tended to sediment (Table I). Cytochrome oxidase, which is regarded as an exclusively mitochondrial enzyme (Roodyn, 1967), was found chiefly in $\mathrm{P}_{2}$ which, 


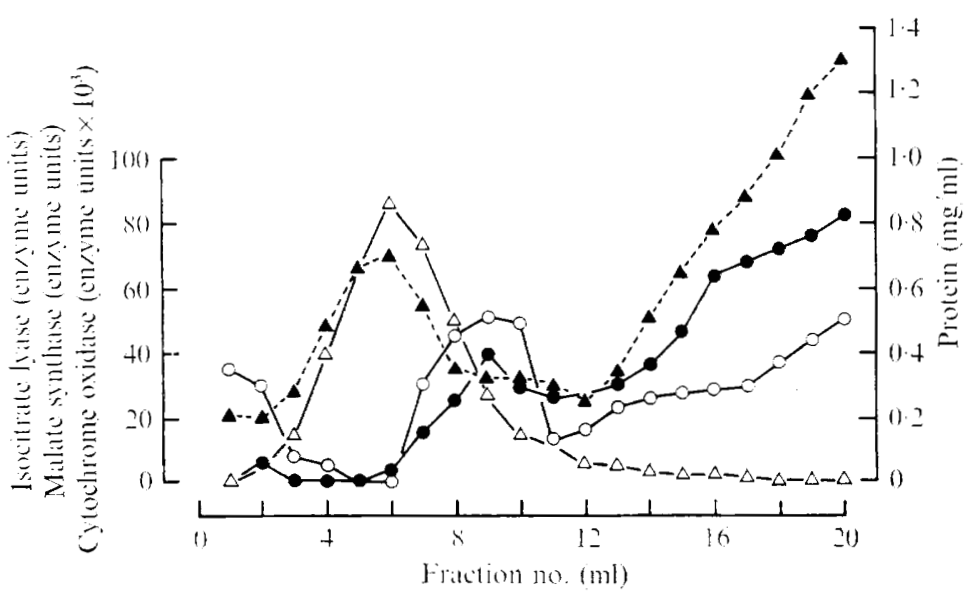

Fig. I. Sucrose density gradient centrifugation of the 10000 to $35000 \mathrm{~g}$ particulate fraction from an extract of Coprinus lagopus. Distribution of protein (A), isocitrate lyase $(0)$, malate synthase $(\bullet)$ and cytochrome oxidase $(\triangle)$.

\section{Table I. Differential centrifugation of an extract of Coprinus lagopus}

Mycelium transferred to acetate medium was extracted in $0.25 \mathrm{M}$-sucrose, containing 0.005 M-EDTA and $\mathrm{c} \cdot 15 \%(\mathrm{w} / \mathrm{v})$ bovine serum albumin, $\mathrm{pH} 7 \%$. The specific activities of the enzymes were measured in the supernatants and sediments from three centrifugation procedures as indicated.

\begin{tabular}{|c|c|c|c|c|}
\hline & $\begin{array}{l}\text { Isocitrate } \\
\text { lyase }\end{array}$ & $\begin{array}{l}\text { Malate } \\
\text { synthase }\end{array}$ & $\begin{array}{c}\text { Malate } \\
\text { dehydrogenase }\end{array}$ & $\begin{array}{l}\text { Cytochrome } \\
\text { oxidase }\end{array}$ \\
\hline \multicolumn{5}{|l|}{$1000 \mathrm{~g} \times 10 \mathrm{~min}$} \\
\hline Supernatant $\left(\mathrm{SI}_{\mathrm{I}}\right)$ & 39 & 255 & 4.9 & 0.048 \\
\hline Sediment $\left(P_{I}\right)$ & 56 & 30 & $2 \cdot 3$ & $c \cdot 043$ \\
\hline \multicolumn{5}{|l|}{$10000 \mathrm{~g} \times 30 \mathrm{~min}$} \\
\hline Supernatant $\left(\mathbf{S}_{2}\right)$ & 38 & I 89 & $4 \cdot 6$ & 0.03 \\
\hline Sediment $\left(\mathrm{Pz}_{2}\right)$ & 153 & 84 & 0.6 & 0.184 \\
\hline \multicolumn{5}{|l|}{$35000 \mathrm{~g} \times 30 \mathrm{~min}$} \\
\hline Supernatant $\left(\mathrm{S}_{3}\right)$ & 42 & I59 & $5 \cdot 0$ & 0.009 \\
\hline Sediment $\left(\mathrm{P}_{3}\right)$ & 380 & 160 & 0.6 & 0.046 \\
\hline
\end{tabular}

therefore, contained most of the mitochondria. The soluble cytochrome oxidase could be due to breakage of mitochondria during the extraction.

Malate dehydrogenase was present in $\mathrm{P}_{\mathrm{I}}$ but was largely absent from $\mathrm{P}_{2}$ and $\mathrm{P}_{3}$. This distribution was also found in extracts of repressed (glucose-grown) mycelium where the level of sedimentable malate dehydrogenase activity was similar. The increased malate dehydrogenase of derepressed cells was found in the supernatant fractions (Table I). Most of the sedimentable isocitrate lyase and malate synthase was found in $\mathrm{P}_{3}$ which would indicate their association with a cell fraction lighter than the mitochondrion.

\section{Sucrose density gradient centrifugation}

The pellets $\mathrm{P}_{2}$ and $\mathrm{P}_{3}$ were combined and centrifuged on a sucrose density gradient. Fractions ( $\mathrm{I} \mathrm{ml}$ ) were collected and assayed for isocitrate lyase, malate synthase and cytochrome oxidase activities. The distribution of these enzymes and of protein content throughout the gradient is shown in Fig. I. Cytochrome oxidase and protein show a peak at fractions 5 to 7 which is taken to correspond to the mitochondrial region. Malate synthase and 
isocitrate lyase coincided in a peak of fractions 8 to Io and this region, which is distinct from and of a lighter buoyant density than the mitochondrion, is regarded as corresponding to a separate particle, the glyoxysome. Malate dehydrogenase was also assayed in the gradient fractions and it showed a peak in the mitochondrial region (fractions 5 to 7 ) but the activity of the enzyme in all fractions was very low.

\section{DISCUSSION}

The growth conditions of the experimental material, the composition of the extraction medium and the severity of the homogenization can all affect the particulate enzyme titre in any localization study. In this work there was a definite separation of two glyoxylate-cycle enzymes from a mitochondrial marker enzyme in differential centrifugation and sucrose density gradient experiments. This indicates the presence of a glyoxysomal structure (Avers, I97I; Tolbert, I97I). For this to be of a lighter buoyant density than the mitochondrion is in contrast to Neurospora crassa (Kobr et al. 1969) but is in agreement with the situation in yeast reported by Szabo \& Avers ( I969). However, other workers have reported only soluble isocitrate lyase activity in extracts of certain fungi (Duntze et al. I969; Cotter, La Clave, Wegener \& Niederpruem, 1970; Perlman \& Mahler, 1970) so that further clarification of the properties of the fungal glyoxysome is necessary (Avers, 197I).

Two isoenzymes of malate dehydrogenase were found in Neurospora crassa grown on acetate but only one of these occurred in cells grown on glucose (Zink \& Shaw, I968). Kobr et al. (1969) have shown that the latter is mitochondrial while the other is glyoxysomal. The apparent existence of three isoenzymes of malate dehydrogenase in Coprinus (unpublished observations), as in yeast (Atzpodien, Gancedo, Duntze \& Holzer, I968), complicates the interpretation of the fractionation data here. Whilst there was no evidence of malate dehydrogenase being associated with the postulated glyoxysome in Coprinus, the low activities of the preparations applied to the sucrose density gradients mean that a particulate location other than the mitochondrion cannot be ruled out.

The authors thank the Science Research Council for financial support, Dr L. A. Casselton for the strain of Coprinus and Miss L. Bullen for technical assistance.

\section{REFERENCES}

Atzpodien, W., Gancedo, J. M., Duntze, W. \& Holzer, H. (I968). Isoenzymes of malate dehydrogenase in Saccharomyces cerevisiae. European Journal of Biochemistry 7, 58-62.

Avers, C. J. (1971). Peroxisomes of yeast and other fungi. Sub-cellular Biochemistry I, 25-37.

BEEVERS, H. (I969). Glyoxysomes of castor bean endosperm and their relation to gluconeogenesis. Annals of the New York Academy of Sciences 168, 31 3-324.

Breidendach, R. W., Kahn, A. \& Beevers, H. (I968). Characterisation of glyoxysomes from castor bean endosperm. Plant Physiology 43, 705-7I 3.

COOPER, T. G. \& BeEvers, H. (I969). Mitochondria and glyoxysomes from castor bean endosperm: enzyme constituents and catalytic capacity. Journal of Biological Chemistry 244, 3507-35I 5.

Cotter, D. A., La Clave, A. J., Wegener, W. S. \& Neiderpruem, D. J. (1970). $\mathrm{CO}_{2}$ control of fruiting in Schizophyllum commune: noninvolvement of sustained isocitrate lyase derepression. Canadian Journal of Microbiology 16, 605-608.

Duntze, W., Neumann, D., Gancedo, J. M., Atzpodien, W. \& Holzer, H. (1969). Studies on the regulation and localisation of the glyoxylate cycle enzymes in Saccharomyces cerevisiae. European Journal of Biochemistry 10, 83-89.

DE Duve, C. (1969). Evolution of the peroxisome. Annals of the New York Academy of Sciences r68, 369-38I.

Flavell, R. B. \& Fincham, J. R. S. (1968). Acetate-nonutilising mutants of Neurospora crassa. II. Biochemical deficiencies and the role of certain enzymes. Journal of Bacteriology 95, 1063-1068. 
FRIES, L. (1953). Factors promoting growth of Coprinus fimetarius (L.) under high temperature conditions. Physiologia Plantarum 6, 551-563.

Hall, D. O. \& Greenawalt, J. W. (1967). The preparation and biochemical properties of mitochondria from Neurospora crassa. Journal of General Microbiology 48, 419-430.

Kobr, M. J., Vanderhaeghe, F. \& Combépine, G. (1969). Particulate enzymes of the glyoxylate cycle in Neurospora crassa. Biochemical and Biophysical Research Communications 37, 640-645.

Kornberg, H. L. (1965). Control of biosynthesis from $\mathrm{C}_{2}$ compounds. In Mécanismes de régulation de activités cellulaires chez les microorganismes, pp. 193-204. Paris: Centre National de la Recherche Scientifique.

KORNBERG, H. L. (1966). Anaplerotic sequences and their role in metabolism. In Essays in Biochemistry, vol. 2. Edited by P. N. Campbell and G. D. Greville. London: Academic Press.

Lowry, O. H., Rosebrough, N. J., Farr, A. L. \& Randall, R. J. (I95I). Protein measurement with the Folin phenol reagent. Journal of Biological Chemistry 193, 265-275.

MÜller, M., HogG, J. F. \& DE DUve, C. (I968). Distribution of tricarboxylic acid cycle enzymes and glyoxylate cycle enzymes between mitochondria and peroxisomes in Tetrahymena pyriformis. Journal of Biological Chemistry 243, 5385-5395.

OсноA, S. (1955). Malic dehydrogenase from pig heart. In Methods in Enzymology, vol. I. Edited by S. P. Colowick and N. O. Kaplan. New York: Academic Press.

Perlman, P. S. \& Mahler, H. R. (1970). Intracellular localisation of enzymes in yeast. Archives of Biochemistry and Biophysics 136, 245-259.

Roodyn, D. B. (1967). The mitochondrion. In Enzyme Cytology. Edited by D. B. Roodyn. New York: Academic Press.

SMITH, L. (1955). Cytochromes $\mathrm{a}_{1} \mathrm{a}_{1}, \mathrm{a}_{2}$, and $\mathrm{a}_{3}$. In Methods in Enzymology, vol. 2. Edited by S. P. Colowick and N. O. Kaplan. New York: Academic Press.

SzABo, A. S. \& AVERS, C. J. (1969). Some aspects of regulation of peroxisomes and mitochondria in yeast. Annals of the New York Academy of Sciences 168, 302-312.

TOLbert, N. E. (197I). Microbodies - peroxisomes and glyoxysomes. Annual Review of Plant Physiology 22, $45-74$.

ZINK, M. W. \& Shaw, D. A. (I968). Regulation of 'malic' isozymes and malic dehydrogenases in Neurospora crassa. Canadian Journal of Microbiology 14, 907-91 2. 